\title{
UTJECAJ AKTIVNE NASTAVE NA UČENJE EKOLOŠKIH SADRŽAJA U OSNOVNOJ ŠKOLI
}

\author{
Elma Kerić1, Ines Radanović2 , Žaklin Lukša $a^{3}$ Diana Garašić, Mirela Sertić Perić2 \\ ${ }^{1}$ Prva privatna gimnazija, Andrije Hebranga 21, 10000, Zagreb \\ elma.keric@gmail.com \\ ${ }^{2}$ Biološki odsjek Prirodoslovno matematičkog fakulteta Sveučilišta u Zagrebu, Rooseveltov trg 6, 10000 Zagreb \\ ${ }^{3}$ Gimnazija Josipa Slavenskog Čakovec, V. Nazora 34, 40000 Čakovec, Hrvatska
}

\begin{abstract}
SAŽETAK
Cilj istraživanja bio je utvrditi koliko aktivno uključivanje učenika u nastavu utječe na kvalitetu stečenih znanja, kao i na motivaciju te stav učenika prema aktivnoj nastavi. Istraživanje je provedeno na uzorku od 64 učenika u tri šesta odjeljenja u osnovnoj školi A.B. Šimića u Zagrebu. Učenici su podijeljeni u eksperimentalnu i kontrolnu skupinu. Eksperimentalna skupina je nastavnu jedinicu Listopadna šuma obradila uz aktivnu nastavu u grupnom, samostalnom i radu u parovima kroz zadatke i nastavu u prirodi. Kontrolna skupina poučavana je klasičnim frontalnim radom nastavnika. Od instrumenata za prikupljanje podataka korištene su tri pisane provjere znanja te anketa za učenike. Pisana provjera provedena je prije istraživanja i nakon svakog provedenog dijela aktivne nastave, a anketiranje učenika na kraju provedenog istraživanja. Rezultati pokazuju povećanu motivaciju, ali i uspješnost učenja u aktivnoj nastavi, a posebno u aktivnostima koje uključuju nastavu u prirodi. Učenici svaku aktivnu tehniku učenja koja im omogućuje slobodu istraživanja i rada izvan učionice doživljavaju pozitivno. Logaritamski oblik regresije bolje objašnjava postignuti uspjeh učenika, ali linearni model još uvijek pokazuje zadovoljavajuću pouzdanost te umanjuje značaj rijetkih pojedinačnih rezultata uspješnosti pa ga je bolje koristiti za prikaz ukupne slike uspješnosti u provjerama znanja. Rezultati istraživanja potvrđuju potrebu korištenja aktivne nastave uz naglasak na boravak učenika u prirodi i korištenje različitih oblika rada koji potiču aktivnost učenika. Na taj način značajno bi se povećalo i zadovoljstvo učenika, ali i njihova uspješnost u učenju.
\end{abstract}

Ključne riječi: uspješnost u učenju, motivacija učenika, stavovi učenika, nastavna tema Listopadna šuma, 6. razred

\section{UVOD}

Prilagođavanje školskog sustava promjenama u društvu nužno je kako bi škole postale centri za doživotno učenje (Dryen and Vos, 2001). U formalnom akademskom obrazovanju i tradicionalnoj nastavi djeca nemaju priliku učiti na zabavan način i putem iskustva, što je temelj za stvarni razvoj te zato prečesto radost učenja blijedi i djeca ne uče kako učiti (Kirschner i sur, 2006). U suvremenoj školi učenik bi trebao biti aktivni sudionik procesa učenja (Jensen, 1995). U cilju osuvremenjivanja nastave u osnovnoj školi i osposobljavanja učenika za cjeloživotno učenje Hrvatski nacionalni obrazovni standard (MZOŠ, 2005) naglašava potrebu smanjivanja opsega akademskih sadržaja u poučavanju, a ističe važnost uvođenja učenika u istraživački usmjerenu nastavu, kao i važnost razvijanja sposobnosti za rješavanje problema i za donošenja odluka. Tako organizirani školski sustav trebao bi maksimalno poticati učenje, stimulirati kreativnost i inventivnost te razvijati sposobnost iniciranja i prilagođavanja promjenama (Baranović, 2006). Učitelji najbolje potiču procese učenja kada posjeduju širok repertoar umijeća poučavanja: pokazivanje, pričanje, raspravljanje, upravljanje skupnim radom (Desforges, 2001). Raznolikost metoda potrebna je zbog raznolikosti nastavnih zadaća i zbog heterogenosti pretpostavki za učenje i interesa učenika. Nastavnici bi trebali pronaći načine motiviranja i poticanja učenika na učenje i to tako da oni u tome uživaju pa Glasser (1994) uspješnog poučavatelja uspoređuje s dobrim trgovcem koji vas uvjeri da baš njegov proizvod želite kupiti i da vas to veseli. Nema nemotiviranog učenika, već postoje privremena stanja nemotiviranosti koja mogu izazvati škole, 
nastavnici ili učenici (Jensen, 1995). U nastavi usmjerenoj na učenika, učenik bi trebao biti aktivniji od nastavnika ili barem jednako aktivan, jer nastava u kojoj učenici samo sjede, slušaju i gledaju ne može zadovoljiti njihove biološke i društvene potrebe te potrebu za samoostvarenjem, njihovu znatiželju i želju za djelovanjem (Matijević, 2008). Terenska je nastava vrlo važna za učeničku motivaciju (Rickinson i sur, 2004) i svakako je jedan od načina aktivnog uključivanja učenika u nastavni proces pa istraživanja brojnih autora ukazuju na njezin pozitivan utjecaj na razvoj socijalnih kompetencija, na usvajanje znanja i razvoj stavova kod učenika (Martin i sur, 1981; Bogner, 1998; Preston i sur, 2004; Dillon i sur, 2006).

Suvremena nastava Prirode i Biologije trebala bi intenzivnije uključiti učenike u nastavni proces (Labov i sur, 2010), poticati ih na upoznavanje svijeta koji ih okružuje te ih usmjeravati učenju življenja u skladu sa prirodom i društvenom zajednicom kojih su dio. Takva nastava trebala bi omogućiti stjecanje trajnih i primjenjivih znanja, razvoju sposobnosti i umijeća. Kako bi što bolje upoznali sve aspekte poučavanja i učenja neophodno je provoditi raznolike analize i rezultate promatrati u različitim aspektima. Istraživači i programeri iz obrazovne zajednice počeli su istraživati potencijale u usvajanju tehnika za stjecanje uvida o učenju (Oyerinde i Chia,2017), što je potrebno kako bi se nastava mogla prilagoditi učenicima.

Istraživanje je provedeno sa svrhom utvrđivanja kako aktivna nastava u vidu učeničkih projekata u sklopu terenske nastave mogu utjecati na kompetencije učenika, ishode njihova učenja i na njihovo zadovoljstvo i motivaciju. Ciljevi istraživanja su utvrditi:

koliko su učenici šestog razreda osnovne škole sposobni sami izraditi projekt u prirodi u sklopu redovite nastave

kakav je stav učenika prema aktivnoj nastavi i posebice terenskoj nastavi

koliko aktivna nastava u obliku projekata učenika i njihovo uključivanje utječe na motivaciju učenika

koliko aktivno uključivanje učenika u nastavu (kroz zadatke, terensku nastavu, grupni rad i rad u parovima) utječe na kvalitetu i trajnost stečenih znanja.

\section{MATERIJALI I METODE}

Istraživanje je provedeno školske godine 2006./2007. u osnovnoj školi A. B. Šimić u Zagrebu uz suradnju nastavnice Vlaste Bendelja. Obuhvatilo je učenike šestih razreda tijekom perioda obrade nastavne cjeline Listopadna šuma koja je podijeljena u 7 nastavnih jedinica. Nastavu je održala Elma Kerić, studentica smjera profesor biologije i kemije PMF-a u Zagrebu. Istraživanje se metodološki zasniva na provedbi pedagoškog istraživanja i na prikupljanju podataka iz neposrednog odgojno-obrazovnog rada. Provedeno je na uzorku od 64 učenika u tri šesta odjeljenja. Učenici 6.a i 6.b odjeljenja činili su ispitnu skupinu, a učenici 6.c odjeljenja činili su kontrolnu skupinu. Kao instrumenti za prikupljanje podataka korištena su tri kompleta pitanja za pismenu provjeru znanja te anketa za učenike.

Na početku istraživanja svi su učenici pisali inicijalnu provjeru znanja kako bi se provjerilo znanje kojim raspolažu prije obrade nastavne cjeline Listopadna šuma te da bi se usporedilo predznanje kontrolne i eksperimentalne skupine. Tijekom obrade nastavne cjeline učenici eksperimentalne skupine proveli su dva samostalna zadatka. Cjelokupna nastava s eksperimentalnom skupinom organizirana je tako da su učenici samostalno, grupno i u parovima aktivno sudjelovali u radu tijekom projekata, odnosno izrade zadataka. I tijekom ponavljanja gradiva izvedenog kroz igru, naglasak je bio na učeničkim aktivnostima. Učenici kontrolne grupe $u$ isto su vrijeme poučavani klasičnim frontalnim oblikom rada uz primjenu

Kerić, E., Radanović, I., Lukša Ž., Garašić, D., Sertić Perić, M. 2017. Utjecaj aktivne nastave na učenje ekoloških sadržaja u osnovnoj školi. Educ. biol. 3, 1, 1-14. 
metode razgovora. Prva provjera znanja provedena je nakon završetka prvog zadatka i ponavljanja. Obuhvaćala je sadržaje iz nastavnog programa prema udžbeniku kojeg su učenici kontrolne skupine koristili u nastavi i tijekom rada na zadacima eksperimentalne skupine. Na taj je način bilo moguće usporediti usvojenost sadržaja obje skupine te utvrditi postoje li razlike između učenika koji su radili na projektnim zadacima i onih koji su prisustvovali samo tradicionalnoj nastavi u školi. Provjera je sadržavala 20 zadataka objektivnog tipa. Druga provjera znanja provedena je nakon završetka drugog zadatka i ponavljanja. Ova provjera obuhvaćala je ukupne sadržaje vezane za nastavnu cjelinu Listopadna šuma.

Prvi zadatak Posjet listopadnoj šumi obuhvatio je i terensku nastavu u prirodi. Učenici su podijeljeni u grupe po 5 učenika uz upute za izvođenje projekta i prezentaciju. Učenici su dobili zadatak posjetiti šumu u blizini škole i promatrati prirodu oko sebe (biljni i životinjski svijet, mirise, boje) te prikupiti materijal koji je, po njihovom kriteriju, karakterističan za određenu šumu. Od prikupljenog materijala bilo je potrebno izraditi plakate na temu Listopadne šume. Učenici su imali 12 dana za izradu zadatka, a rezultate su trebali prezentirati ostalim učenicima u razredu. Svaka grupa dobila je tri ocjene koje obuhvaćaju kreativnost, korištenje dodatne literature i izlaganje. Na ovaj način željelo se potaknuti učenike da se više posvete promatranju svijeta oko sebe i boravku u prirodi. Također se potaknuo natjecateljski duh kao i međusobna suradnja. Promatralo se koliko oni doista uživaju u posebnim zadacima i koliko to utječe na njihovo znanje. Učenici su radili u grupama i imali 12 dana za izradu zadatka i prezentacije. Svaka grupa je dobila tri ocjene koje obuhvaćaju kreativnost, korištenje dodatne literature i izlaganje. Namjena zadatka bila je kroz učenički boravak u prirodi razviti vještine promatranja kao osnove za zaključivane.

$\mathrm{U}$ drugom zadatku učenici su podijeljeni u parove uz upute za izvođenje zadatka kooperativnog učenja sa izradom eseja na temu Zaštićenih životinjskih vrsta listopadne šume ili na temu Ljekovitih biljaka listopadne šume. Zadatak svakog para bio je pronaći u literaturi najmanje 3 biljne ili životinjske vrste i detaljno ih obraditi. Učenici su dobili i detaljne upute za pisanje eseja. Za provedbu zadatka imali su 14 dana i na kraju su trebali prezentirati svoj rezultat u obliku eseja. Ovim se projektnim zadatkom nastojalo kod učenika potaknuti razvijanje prirodoslovne pismenosti i usmjeriti ih na služenje dodatnom literaturom pa je kao obrazovni izvor korišten i Internet. Svaki je par dobio jednu zbirnu ocjenu koja je uključivala ocjenu za kreativnost, korištenje izvora znanja, oblikovanje teksta i izlaganje.

Prva provjera odnosila se na provjeru predznanja (inicijalna provjera). Kratkim petminutnim testom učenici su potaknuti na razgovor i raspravu o listopadnoj šumi. Budući da su učenici znali većinu odgovora na pitanja iz inicijalnog ispita željeli su podijeliti svoje znanje sa nastavnikom i međusobno. Poznavanje materije probudilo je u njima dodatnu motivaciju, jer se ne susreću sa potpuno nepoznatim sadržajima već posjeduju određeno znanje koje žele i prezentirati. Druga provjera znanja provedena je nakon završetka prvog projekta i ponavljanja, a obuhvaćala je gradivo prema nastavnom planu i programu vezana za gradivo u udžbeniku i nije bilo pitanja vezanih isključivo za provedeni projektni zadatak eksperimentalne skupine. Treća provjera znanja izvršena je nakon završetka zadatka kooperativnog učenja i ponavljanja na isti način kao i prva. Obuhvaćala je ukupno gradivo vezano za nastavnu cjelinu Listopadna šuma. Pitanja su bila vezana isključivo za nastavne sadržaje prezentirane u udžbenicima, jer se željelo provjeriti postoji li razlika u usvojenosti gradiva kod učenika ovisno o tome jesu li radili na projektu ili su prisustvovali samo redovitoj nastavi u školi. Učenici su pisali provjeru objektivnog tipa od 20 pitanja u trajanju od 30 minuta.

Kerić, E., Radanović, I., Lukša Ž., Garašić, D., Sertić Perić, M. 2017. Utjecaj aktivne nastave na učenje ekoloških sadržaja u osnovnoj školi. Educ. biol. 3, 1, 1-14. 
Tijekom nastave učenici su učili kako sa razumijevanjem pročitati i obraditi određeni tekst, budući da učenici ne znaju kako pristupiti obradi opširnijeg teksta koji čini svaku nastavnu jedinicu u udžbeniku. Poseban problem u obradi teksta bilo je razlučiti važno od manje važnog i obraditi tekst u obliku natuknica za učenje. Učenici su upoznali tri načina učenja uz rad na tekstu u smislu podrške generičke kompetencije „učiti kako učiti“. Prvi oblik učenja uz rad na tekstu bilo je traženje odgovora na pitanje postavljeno u radnom listiću i prezentiranje odgovora ostatku razreda. Učenici su podijeljeni u pet grupa i svaka je grupa dobila jedno pitanje. Radilo se na tekstu iz udžbenika vezanom za nastavnu jedinicu Osnovna obilježja kontinentalne listopadne šume. Drugi oblik učenja uz rad na tekstu bilo je naučiti razlučiti važne činjenice od manje važnih izvlačenjem natuknica iz teksta Cilj zadatka bilo je otkriti zašto postoji razlika u bojama teksta (različiti slojevi u šumi). Učenici su dobili gotovi tekst u dvije boje kako bi lakše postigli željeni rezultat. Drugi oblik rada na tekstu bio je vezan uz nastavne jedinice Prizemni sloj kontinentalne listopadne šume i Sloj grmlja kontinentalne listopadne šume. Treći oblik bio je izrada mentalnih mapa. Na temelju teksta u udžbeniku uz nastavne jedinice Povezanost biljaka i životinja u šumi i Iskorištavanje i zaštita šuma morali su napraviti mentalnu mapu i prezentirati je ostatku razreda. Osim rada na tekstu nastavna jedinica Sloj drveća u listopadnoj šumi obrađena je na temelju učeničkih plakata iz prvog zadatka. Materijali sa plakata upotrijebljeni su za upoznavanje učenika sa drvećem koje nalazimo u listopadnim šumama.

Ponavljanje gradiva provedeno je u obliku igara kako bi učenici bolje usvojili i sistematizirali obrađeno gradivo. Ponavljanje kroz igru odabrano je jer svi učenici lakše prihvaćaju ponavljanje i učenje u obliku igre, razlika je samo u odabiru igara i njihovoj prilagodbi određenom uzrastu. $U$ dobi od 12 godina učenici su zaigrani i mnogo lakše prihvaćaju svaki oblik rada koji je njima blizak i koji će im omogućiti da se zabave dok uče.

Po završetku istraživanja provedena je anketa među učenicima sa ciljem prikupljanja podataka o njihovom vlastitom doživljaju nastave i primjeni projekata pri čemu su učenici kontrolne skupine bili izvješteni o tehnikama rada koje su primijenjene u eksperimentalnim skupinama. Provedena je anketa među razrednicima kako bi se prikupili podaci o doživljaju nastave, odnosima unutar razreda kao i među razredima. Anketu je ispunila i nastavnica koja vodi učenike u učenju predmeta Prirode, kako bi se dobili podaci o odnosu učenika prema nastavi Prirode. Statističke analize i grafički prikazi provedene su primjenom paketa analize podataka Microsoft Excel.

\section{REZULTATI}

Analizom općih karakteristika učenika eksperimentalne i kontrolne skupine utvrđeno je da je opći uspjeh učenika znatno povezan s njegovim radom tijekom nastave (slika 1).

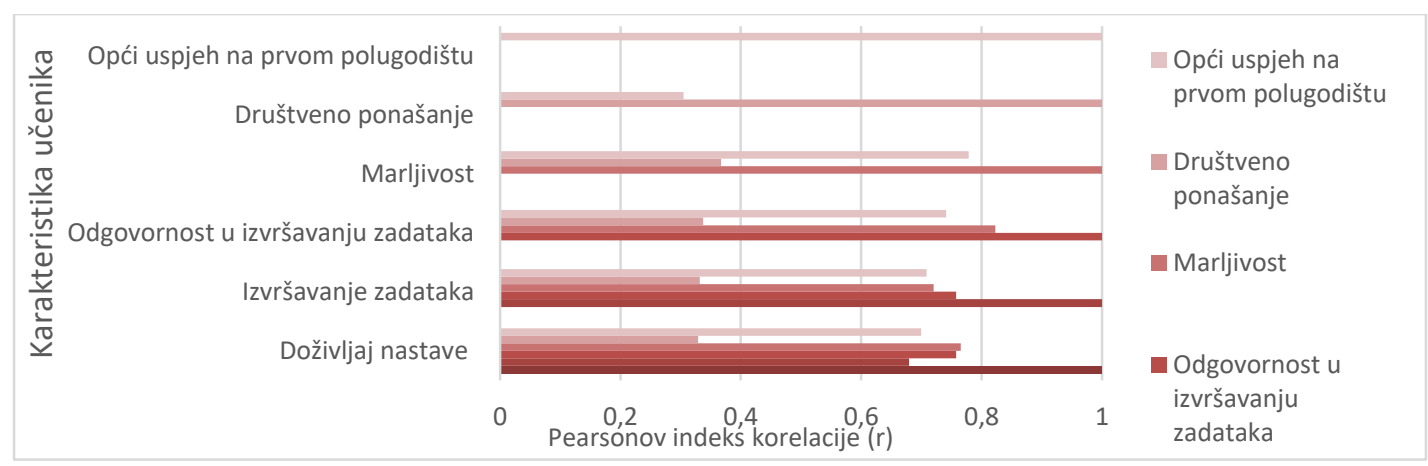

Slika 1 Korelacije procjene općih karakteristika učenika

Kerić, E., Radanović, I., Lukša Ž., Garašić, D., Sertić Perić, M. 2017. Utjecaj aktivne nastave na učenje ekoloških sadržaja u osnovnoj školi. Educ. biol. 3, 1, 1-14. 
Marljivi učenici pokazuju veliku odgovornost pri rješavanju zadataka uz pozitivan doživljaj nastave i ažurno rješavanje zadataka. Za razliku od toga društveno ponašanje uspješnih učenika znatno je slabije razvijeno.

\section{Rezultati pisanih provjera}

Nije utvrđena statistički značajna razlika između učenika u uspješnosti rješavanja inicijalnih provjera, te je time omogućena uopćena usporedba rezultata svih odjeljenja, jer su učenici pokazali podjednake sposobnosti i mogućnosti. Uspješnost u rješavanju provjera tijekom istraživanja opada vrlo vidljivo kod kontrolnog odjeljenja, dok odjeljenja uključena u aktivnu nastavu pokazuju bolje rezultate. Kontrolno odjeljenje ima posebno loše rezultate u posljednjoj provjeri (slika 2).

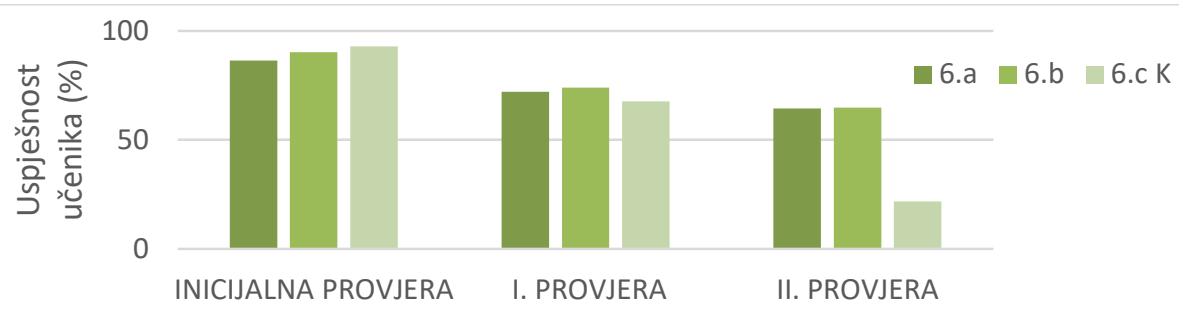

Slika 2 Postotni udio uspješnosti po odjeljenjima pri rješavanju provjera

Razlika uspješnosti u provjeri znanja vidljiva je u pisanoj provjeri nakon drugog projektnog zadatka kada je su učenici kontrolnog odjeljenja postigli samo 22 \% riješenosti u odnosu na po 65 \% riješenosti koju su ostvarila eksperimentalna odjeljenja (slika 2). Inicijalnu pismenu provjeru najbolje je riješilo kontrolno odjeljenje, a ispite nakon prvog i drugog zadatka najbolje je riješilo odjeljenje 6.b razreda. Razlike uspješnosti u provjeri znanja između eksperimentalnih odjeljenja nisu statistički značajne (slika 2).

Pri usporedbi aktivnog učenja uz projektne zadatke i tradicionalnog poučavanja uz razgovor s učenicima na primjeru jednog pitanja koje je vezano uz osnovne karakteristike listopadne šume, odnosno gubitak lišća listopadnog drveća, može se uočiti da na reproduktivnoj razini nema značajnijih razlika u odnosu na inicijalni odgovor učenika, jer je u oba navrata riješenost zadataka 63 \% (slika 3). Za razliku od toga kod završne provjere na kraju istraživanja gdje je u kratkom odgovoru traženo objašnjenje razloga gubitka lišća, uočeno je da je 12 \% učenika moglo pružiti potpuno objašnjenje koje je uključivalo elemente konceptualnog razumijevanja, dok je 39 \% učenika ponudilo djelomično točan odgovor na reproduktivnoj razini, a $49 \%$ učenika nije ponudilo dobro objašnjenje.

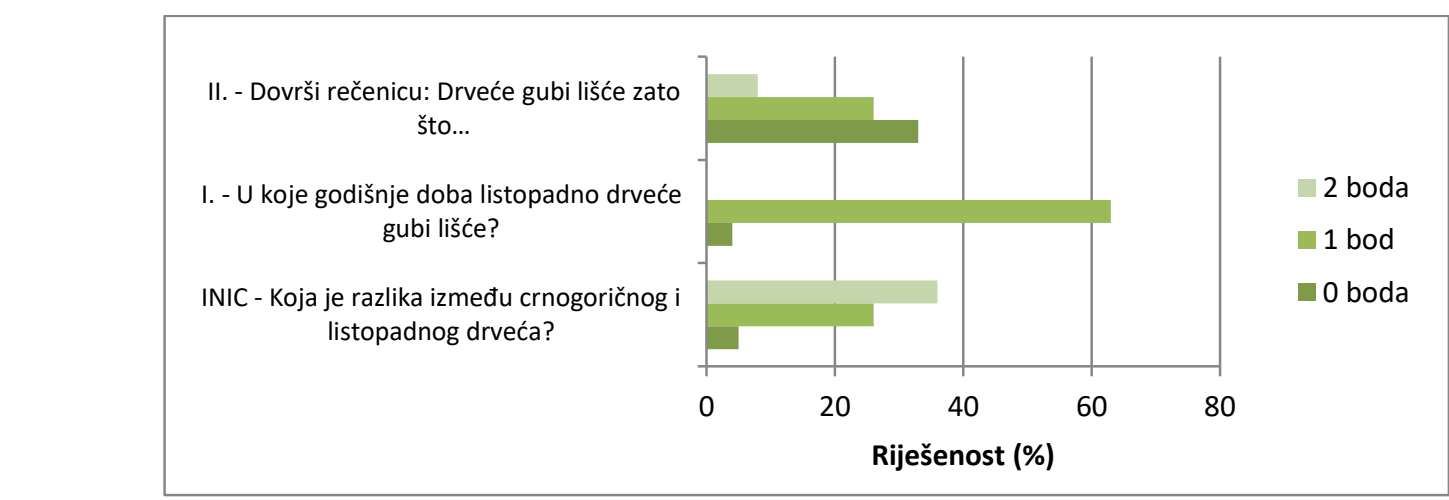

Slika 3 Riješenost provjera s obzirom na ostvarene bodove

Kerić, E., Radanović, I., Lukša Ž., Garašić, D., Sertić Perić, M. 2017. Utjecaj aktivne nastave na učenje ekoloških sadržaja u osnovnoj školi. Educ. biol. 3, 1, 1-14. 
Pri analizi uspješnosti učenja utvrđenoj na osnovu pisanih provjera znanja tijekom obrade nastavne teme Listopadna šuma, potvrđene su očekivane signifikantne razlike u rješenju I. i II. pisane provjere $\left(F_{(3,91)}=6,96 ; p<0,009\right)$. Analiza varijanca rješenja svakog pojedinog učenika ukazuje na eksponencijalni regresijski trend i mogućnost svrstavanja učenika u skupine prema postotnoj varijaciji uspješnosti (slika 4).

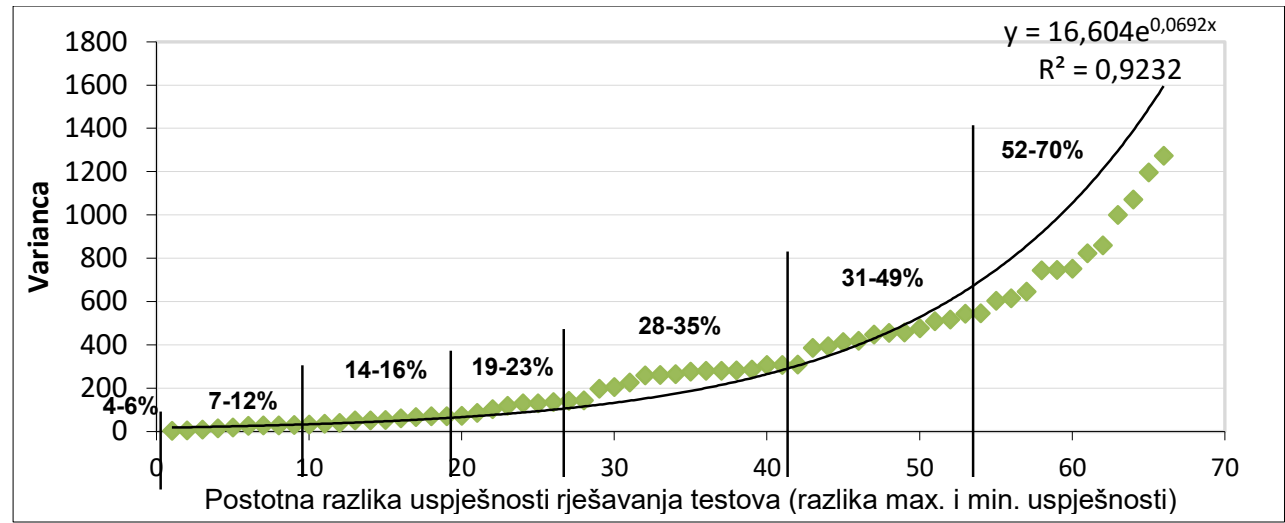

Slika 4 Eksponencijalni trend stalnosti uspjeha pojedinog učenika u provjerama znanja

Podaci dobiveni istraživanjem pokazuju da uspješnost učenja uz zadatke raste i da je rast izraženiji i bolji nakon prvog zadatka dok je nakon drugog zadatka nešto sporiji i nepravilniji, ali da dostiže $100 \%$ (slika 5).

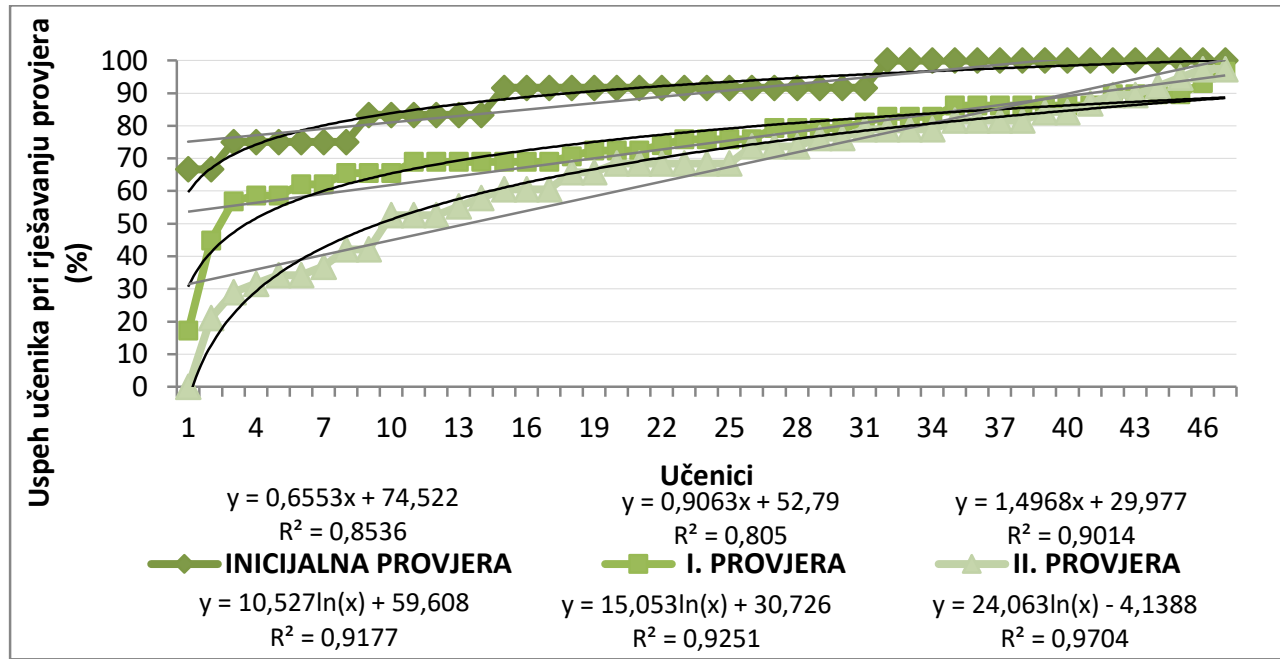

Slika 5 Uspješnost učenja uz zadatke prema riješenosti provjera

Na slici 5 može se uočiti da logaritamski oblik regresije bolje objašnjava postignuti uspjeh učenika $\left(R^{2}=\right.$ $0,92 ; 0,93 ; 0,97)$. Usprkos tome linearni model regresije još uvijek pokazuje zadovoljavajuću pouzdanost $\left(R^{2}=0,85 ; 0,81 ; 0,90\right)$, ali i umanjuje značaj rijetkih pojedinačnih rezultata uspješnosti, te je linearni model bolje koristiti za prikaz ukupne slike uspješnosti u provjerama znanja. Pri tome manji odsječak na osi y pokazuje slabiju uspješnost pri rješavanju zadataka, a položenost regresijske linije ukazuje na veću ujednačenost uspjeha kod ispitivanih učenika.

Usporedbom slike 5 sa slikom 6 može se uočiti da je uspješnost učenja prisutna i kod kontrolnog odjeljenja te i tamo raste, ali je ukupno slabija nego kod eksperimentalnih odjeljenja. Nije utvrđena statistički značajna razlika u uspješnosti učenja, što ukazuje na kvalitetnu nastavu uz razgovor koja se

Kerić, E., Radanović, I., Lukša Ž., Garašić, D., Sertić Perić, M. 2017. Utjecaj aktivne nastave na učenje ekoloških sadržaja u osnovnoj školi. Educ. biol. 3, 1, 1-14. 
većim dijelom primjenjuje u radu s učenicima i osigurava učenje s $57 \%$ uspjeha. Za razliku od toga učenici koji su učili uz projektne zadatke i različite aktivnosti ostvarili su 66 \% uspješnosti učenja.

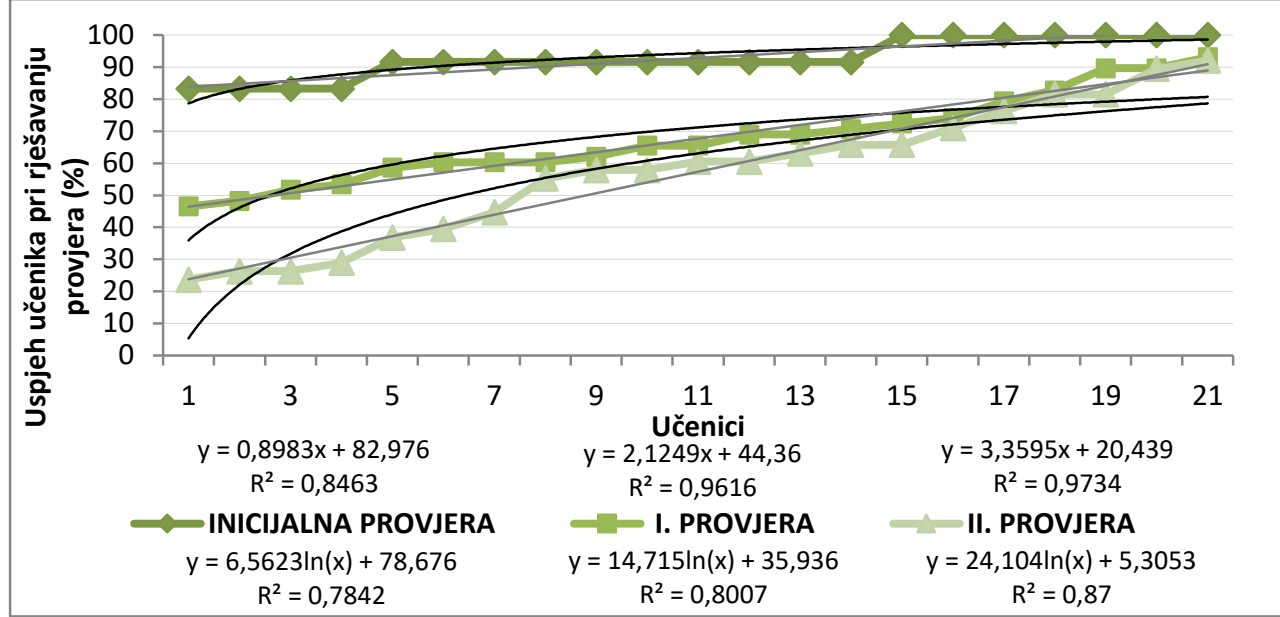

Slika 6 Uspješnosti učenja kontrolnog odjeljenja

Klaster analiza uspješnosti provjera (Distance/Similarity Measure = Bray and Curtis; Cluster Method = Nearest Neighbour) ukazuje na najveću sličnost uspjeha učenika pri rješavanju provjera iste grupacije (slika 7), što je u skladu sa zahtjevima pojedine provjere.

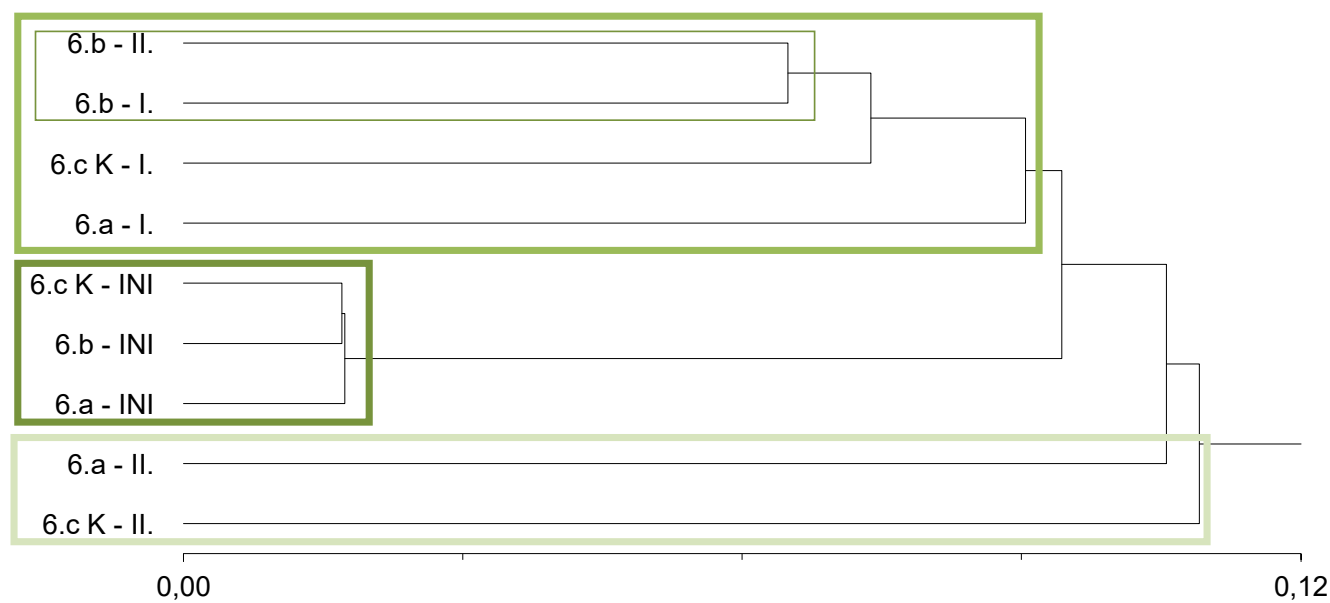

Slika 7 Klaster-dijagram uspješnosti učenika u sklopu pojedinih odjeljenja pri rješavanju provjera INI - inicijalna, I: - prva provjera, II. - druga provjera

Pri analizi klaster dijagrama vidljiva je i veća uspješnost nakon prvog zadatka. To možemo objasniti činjenicom da velik broj učenika u anketi ocjenjuje prvi zadatak zanimljivijim zbog terenske nastave. Taj podatak govori o vjerojatno većoj motivaciji koja je mogla utjecati na bolji rezultat učenja. Pisana provjera II. 6.b odjeljenja izdvaja se po uspješnosti i više odgovara riješenosti I. pisane provjere kod svih odjeljenja.

\section{Analiza ankete učenika}

Učenici su u visokom postotku u sva tri odjeljenja procijenili da nastavu Prirode doživljavaju vrlo zanimljivom, a u njoj postižu i vrlo dobre rezultate (slika 8). Anketom je ispitano što se učenicima sviđa na nastavi Prirode pa se pokazalo da izuzetno pozitivno reagiraju na rad u grupi, kao i na učenje kroz igru i zabavu (tablica 1). Učenici eksperimentalnih odjeljenja dobro su prihvatili istraživanje ocijenivši

Kerić, E., Radanović, I., Lukša Ž., Garašić, D., Sertić Perić, M. 2017. Utjecaj aktivne nastave na učenje ekoloških sadržaja u osnovnoj školi. Educ. biol. 3, 1, 1-14. 
ga srednjom ocjenom 4,0 dok kontrolno odjeljenje (6.c) nije dobro prihvatilo istraživanje ocijenivši ga srednjom ocjenom 1,5 .

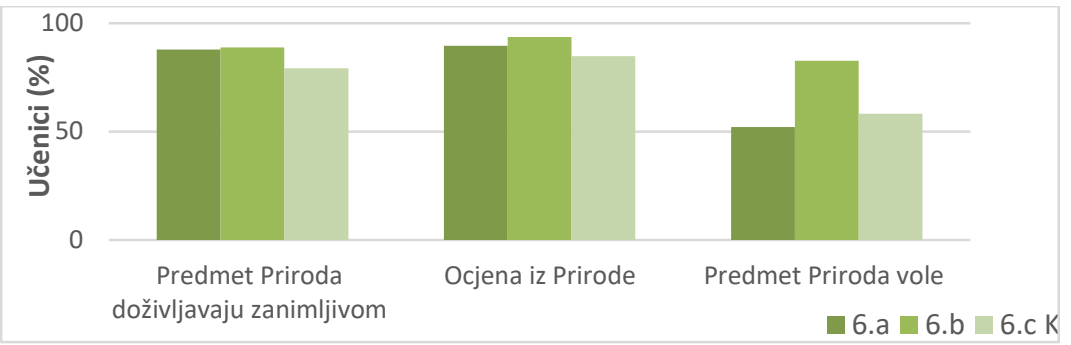

Slika 8 Stav učenika prema predmetu Priroda

Učenici kontrolnog odjeljenja posebno su negativno ocijenili svoju izoliranost od aktivne nastave i nemogućnost natjecanja sa drugim odjeljenjima. Srednja ocjena kojom su učenici procijenili način rada tijekom nastave je $3,7 \pm 0,47$.

Tablica 1 Procjena učenika o oblicima i načinu rada

\begin{tabular}{|c|r|c|c|c|}
\hline \multirow{2}{*}{ Kategorija pitanja } & Anketna pitanja & \multicolumn{3}{|c|}{ Odjeljenje } \\
\cline { 2 - 4 } & & $\mathbf{6 . a}$ & $\mathbf{6 . b}$ & $\mathbf{6 . c} \mathbf{K}$ \\
\hline \multirow{2}{*}{ RAD TIJEKOM NASTAVE } & grupni rad & 4 & 4 & 4 \\
\cline { 2 - 5 } & rad na tekstu & 3 & 4 & 3 \\
\hline
\end{tabular}

$65 \%$ učenika eksperimentalnih odjeljenja jako je zadovoljno primijenjenim načinom rada, dok takav način rada nije odgovarao 2 \% učenika (slika 9). Većina učenika (71 \%) uz mogućnost samostalnog rada treba dobru potporu i usmjerenje kao i sistematizaciju nastavnika, što se može vidjeti u prepoznavanju najboljeg učinka učenja i prema mišljenju učenika (slika 9).

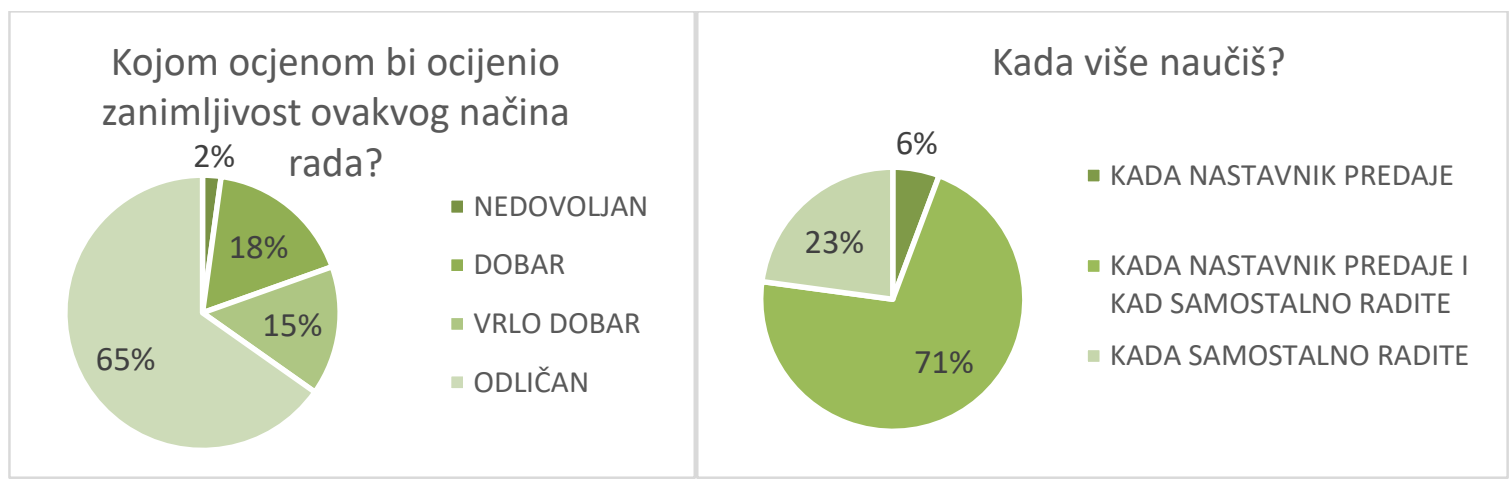

Slika 9 Učenička procjena zanimljivosti učenja uz projektne zadatke te uspješnosti učenja s obzirom na način rada

U stavovima učenika o tome što im se sviđa u nastavi Prirode ističe se pozitivan stav prema aktivnostima izrade mentalnih mapa i upoznavanja životinja koji iskazuje više od $5 \%$ učenika. Ostale aktivnosti izabire manje od $5 \%$ učenika. Više od $10 \%$ učenika izabralo je sve ponuđene odgovore, jer ništa nisu mogli posebno izdvojiti. Najbolje prihvaćenim pokazao se rad u grupi, $18 \%$ odgovora. Aktivnosti učenika procijenjene su srednjom ocjenom 4,7 , ali utvrđene su signifikantne razlike u prihvaćanju aktivnosti $\left(F_{(2,66)}=3,68 ; p<0,01\right)$. Najnižom ocjenom ocijenjen je radni listić na temelju plakata $(3,7)$. Srednjom ocjenom 5,0 procijenjeno je korištenje dvobojnog teksta, natjecanje, igra zijevalica, izrada mentalne mape. Kontrolno odjeljenje 6.c procijenilo je nižom ocjenom od odjeljenja 6.a i 6. b aktivnosti: izlazak pred ploču, usmeni opis mentalnih mapa, korištenje literature. Kontrolno 
odjeljenje 6.c najnižom je ocjenom ocijenilo radne listiće na temelju učeničkih plakata (slika 9), što je razumljivo jer oni nisu izrađivali plakate na osnovu kojih su učili.

Analiza stavova učenika o zadacima pokazala je da se rad na zadacima svidio većini učenika (6.a $=87 \%$, $6 . b=91 \%$ učenika). Prvi zadatak je bolje prihvatilo $54 \%$ učenika (srednja ocjena: $6 . a=4.6,6 . b=4.4$ ). Drugi zadatak je bio prihvatljiviji za 39\% učenika (srednja ocjena: $6 . a=4.4,6 . b=4.4$ ). Oba zadatka su se jednako svidjela udjelu od $7 \%$ učenika. Prema iskazima u anketi prvi zadatak više se svidio učenicima najviše zbog zanimljivosti, rada u grupi, posjeta šumi, lakšeg dogovora i zbog boljeg razumijevanja.

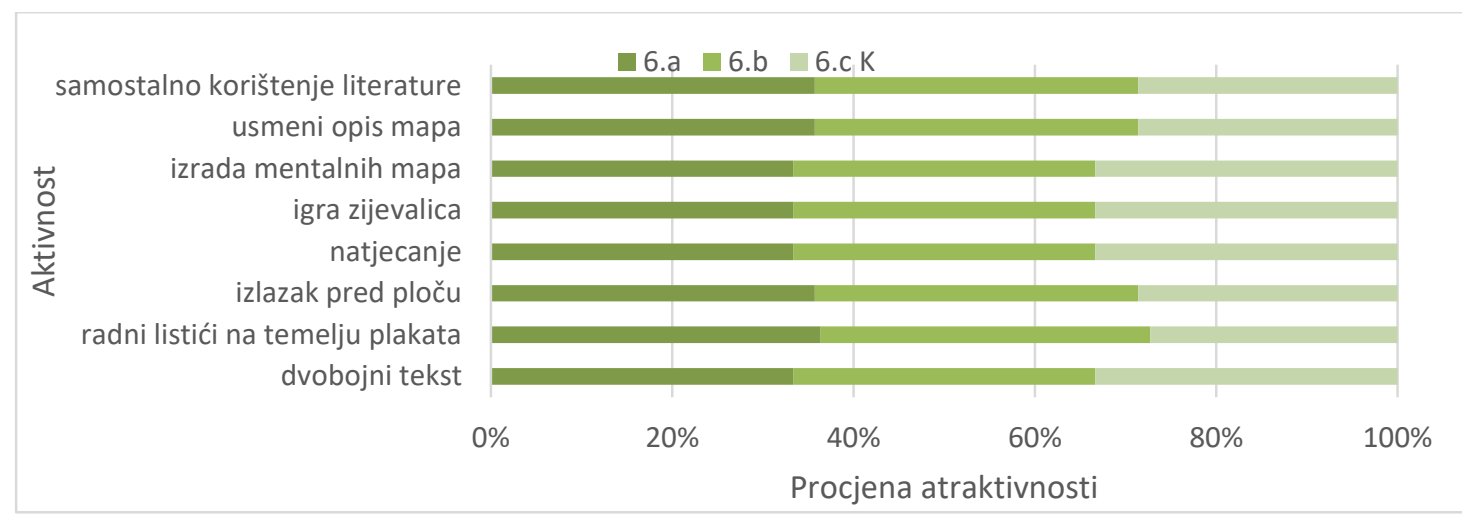

Slika 10 Srednje procjene učenika za provedene aktivnosti

Kod provjere znanja čak $64 \%$ učenika preferira pisani oblik provjere znanja, njih $30 \%$ usmeni oblik, dok $6 \%$ učenika nije izabralo ni jedan oblik provjere znanja. Ponavljanje kroz igru s nagradama (bomboni ili plusevi) učenicima je vrlo zanimljivo i privlačno pa se za taj oblik ponavljanja odlučilo $89 \%$ učenika, a samo $11 \%$ smatra da je bolja igra bez nagrada.

Iz slike 11 vidljivo je da su učenici uspješnije riješili projektni zadatak 1, ali i da je 6.a odjeljenje bilo uspješnije u rješavanju oba zadatka.

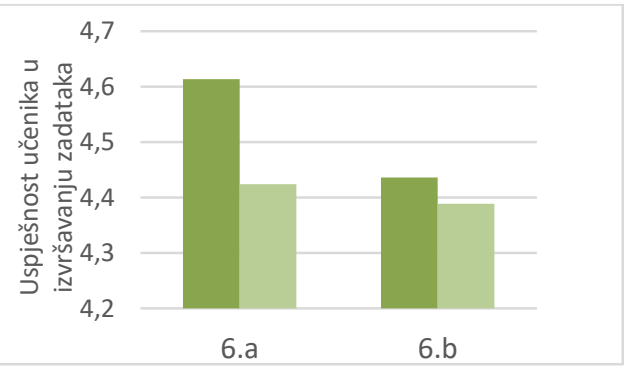

Slika 11 Srednja ocjena uspješnosti učenika pri izradi projektnih zadataka

Usprkos toga uočene razlike između uspjeha učenika u različitim odjeljenjima nisu signifikantne i omogućuju zajedničku interpretaciju rezultata. $91 \%$ učenika smatra da je više naučilo radeći na zadacima i stoga takav način rada želi i ubuduće, dok $9 \%$ učenika ne prihvaća nastavu koja uključuje aktivne zadatke i smatra da to ne pridonosi boljim rezultatima učenja.

Učenici su posebno uživali u aktivnoj nastavi zbog toga što im je ona zabavnija zbog rada u grupi, rada u paru i mogućnosti rada na otvorenom. Rezultati ankete pokazuju da 70\% učenika nakon završetka istraživanja smatra da im je zanimljivo učiti o listopadnim šumama preko projekatnih zadataka i tijekom terenske nastave. Samoprocjenom je 91\% učenika eksperimentalnih odjeljenja koji su sudjelovali u 
aktivnostima učenja uz projektne zadatke, zaključilo da znaju više o listopadnim šumama nego na početku istraživanja. Čak $98 \%$ učenika sve dobivene upute u nastavi smatra vrlo jasnima i preciznima, a $91 \%$ učenika i ubuduće želi raditi na zadacima.

\section{RASPRAVA}

U suvremenoj nastavi naglasak više nije na usvajanju činjenica već se ističe razvoj učeničkih kompetencija i osposobljavanja učenika za samostalni život. Učenici uključeni u aktivnu nastavu tijekom istraživanja vrlo su dobro reagirali, dok učenici kontrolne skupine nisu dobro prihvatili istraživanje. lako su učenici kontrolnog odjeljenja na nastavi bili uključeni u jednake aktivnosti, nisu sudjelovali u projektnim zadacima i terenskoj nastavi. Smatrali su stoga, što potvrđuju rezultati ankete, da su zakinuti za zanimljiv i zabavan dio nastave i na to nisu dobro reagirali. U školi i na nastavi svi učenici podjednako žele sudjelovati u svim aktivnostima i vrlo im je bitno da budu dio cjeline. Ne vole kada ih se izdvaja, kada su odvojeni i ne sudjeluju u nečemu za što su sigurni da je zanimljivo i zabavno. Takve reakcije učenika potvrđuje i Bilić (2001).

U procjeni oblika rada svi učenici najbolje su ocijenili suradničko učenje uz grupni rad, a vrlo je dobro ocijenjen i rad u paru. Učenici radom u grupama razvijaju vještine, usvajaju nova znanja ali i razvijaju socijalne kompetencije što potvrđuju brojni autori (Slavin, 1995; Lukša, 2007; Borresen, 2006). Bilić (2001) također ukazuje da se tijekom zajedničkih aktivnosti stvaraju različiti odnosi među učenicima, izgrađuje pozitivan stav o sebi, ali se razvijaju i stavovi o standardima poželjnih i odgovarajućih osobina. Nedostatak ovih oblika rada kod kontrolne grupe uzrokovao je pad motivacije (Lorenzo i sur, 2006), što je utjecalo na manju uspješnost ove skupine učenika i na svim pisanim provjerama znanja, osim na inicijalnoj provjeri koja pokazuje predkoncepcije i retenciju znanja. Na uspješnost učenja osim suradničkog učenja utjecala je i primjena aktivnog učenja kojim prema Dryen, Vos (2001) učenici upamte $90 \%$ naučenoga. U procjeni različitih tipova rada učenici su najlošije reagirali na rad bez ocjenjivanja. Ocjena je za njih kao dio školskog sustava važan pokazatelj uspješnosti i vjerojatno utječe na motivaciju što potvrđuju brojni autori (Ros i Gott, 2003). Bilić (2001) ističe da zdrava konkurencija potiče učenike na pozitivne napore u postizanju uspjeha, no važno je da ocjena ne ostane i jedina učenička motivacija.

Rezultati analize državne mature iz biologije (Radanović i sur, 2017) podupiru rezultate ovog istraživanja da je u pripremi pisanih provjera neophodno učenike tražiti objašnjenja. Ovim je istraživanjem utvrđeno da i na razini provjere bazičnih neophodnih reproduktivnih znanja treba učenike privikavati da uz odgovor nude objašnjenje, jer se samo na taj način može napraviti poveznica prema konceptualnom razumijevanju i omogućiti izgradnja koncepata.

Uspješnost učenja ukazuje na eksponencijalni regresijski trend i mogućnost svrstavanja učenika u skupine prema postotnoj varijaciji uspješnosti. Rezultati pokazuju kako su učenici bili uspješniji u rješavanju prvog zadatka i da im je prvi zadatak bio draži od drugog. Prvi zadatak uz terenski zadatak omogućio je učenicima da nastavu Prirode dožive kao nastavu u prirodi (Garašić, 2012) jer im je omogućio samostalan odlazak u prirodu, rad u grupama, skupljanje i slaganje materijala te njegovo prezentiranje. Abrahams (2009) predlaže da se termin motivacija u kontekstu praktičnog rada zamijeni terminom situacijski interes, jer za razliku od motivacije ili osobnog interesa, će situacijski interes vjerojatno izdržati nakon kraja određenog nastavnog sata (Hidi i Harackiewicz, 2000) te pomaže u objašnjenju zašto se učenici moraju stalno stimulirati kroz čestu uporabu praktičnog rada, odnosno 
različitih oblika aktivnosti tijekom nastave. Mogućnost boravka u prirodi, neposrednog upoznavanja sa prirodom i njezinim zakonitostima potiče motivaciju, pruža učenicima osjećaj samostalnosti i sposobnosti za otkrivanjem novog i nepoznatog. Takve rezultate istraživanja potvrđuje i Jensen (1995) koji ističe da najbolje poticanje učenikove motivacije omogućuje pobuđivanje znatiželje uz izazovne aktivnosti i očekivanja, a tada je učenik spreman primiti podatke ili informacije koje će, kada se povežu s drugim relevantnim asocijacijama, stvoriti značenje i oblikovati ono što se zove znanje. Rezultati uspješnosti ovog zadatka potvrđuju da dobro osmišljen zadatak terenske nastave potiče motivaciju učenika i olakšava savladavanje nastavnog programa. Slične rezultate pokazuju i istraživanja još nekih autora koji ističu upravo dobru pripremljenost i jasnoću uputa u primjeni terenske nastave (Bilić, 2001; Dillon i sur, 2006). Tako Siendetop (1971) ističe da posebnu pozornost učenju i poučavanju prirode zaslužuje pristup koji podržava i razvija autonomnost temeljenu na iskustvu. Ta činjenica ukazuje da učenicima treba omogućiti nastavu prirode u prirodi gdje bi oni vlastitim radom dolazili do pojedinih spoznaja i zaključaka, što ističu i Borić i Peko (1998). Rezultati istraživanja pokazuju da učenici najbolje reagiraju na inventivniji i zahtjevniji pristup nastavi koja ih potiče da se uključe, budu aktivni i sudjeluju te takva nastava dovodi do najviših rezultata. I prema Matijeviću (2008), aktivnosti učenika, u odnosu na druge strategije učenja, više pridonose stjecanju znanja, ali i razvijanju vještina i podizanju motivacije za učenje i druge nastavne aktivnosti. U nastavi Prirode šestog razreda mogu se primijeniti najrazličitiji načini i oblici rada te iskoristiti mnoštvo ideja jer je Priroda, kao rijetko koji predmet bogata praktičnim i svakodnevnim primjerima iz života. Najvišom ocjenom učenici su ocijenili upravo takav način rada (igra zijevalice, dvobojni tekst, natjecanje, izrada mentalne mape).

Drugi projektni zadatak bio je vezan uz razvoj prirodoslovne pismenosti i od učenika je tražio upoznavanje literature i korištenje Interneta, odnosno boravak u zatvorenom prostoru, uz puno čitanja i kritičkog razmišljanja. U odnosu na terenski zadatak, takav način rada većina učenika ipak je doživjela kao manje zanimljiv. Kod eksperimentalne grupe uz zadatke, uspješnost učenja raste i rast je izraženiji i bolji nakon prvog zadatka, dok je nakon drugog zadatka nešto sporiji i nepravilniji, ali dostiže $100 \%$ uspješnosti učenja kod većeg broja učenika. Učenici u dobi od 12 godina su još vrlo zaigrani, uživaju pokazivati svoju kreativnost i dolaziti do novih spoznaja neposrednim kontaktom (Jokić, 2008) dok im je ideja o sjedenju i proučavanju literature pomalo odbojna. Zato je i uspješnost učenja nakon prvog zadatka imala intenzivniji rast nego nakon drugog zadatka. Takvom pristupu učenja biologije daje potporu i Hodson (1996) koji ističe da je učenje sadržaja prirode uspješnije s dokazima iz prve ruke i iskustvom na terenu. Takav zaključak potvrđuju Greaves i sur. (1993) koji ističu da podaci koji nisu dobiveni iz prve ruke često učenike ostavljaju nedostatno informiranim i nedovoljno osviještenim.

Jedan od bitnih čimbenika u prihvaćanju projektnog učenja bio je i dobar odnos učenik-učitelj zbog kojeg su učenici pozitivno reagirali na aktivnu nastavu i izrazili želju da i ubuduće sudjeluju u takvim aktivnostima. Pozitivno su ocijenili i nastavnika iako se ne može zanemariti da je $11 \%$ učenika ocijenilo nastavnika ocjenom dobar i da je većina tih učenika iz kontrolnog odjeljenja. Tu je ponovno bitan osjećaj prihvaćenosti i jednakog odnosa prema svima koji je zbog zadaće kontrolne grupa prema njima izostao.

Većina učenika preferira kombinaciju nastavnikova strukturiranog vođenja i samostalnog rada, manji broj kada rade samostalno, a samo $6 \%$ učenika odobrava tradicionalni predavački frontalni rad nastavnika. Takav stav učenika odgovara zaključku da većini učenika odgovara strukturirano vođeno aktivno učenje u odnosu na slobodno istraživačko učenje (Kirschner i sur, 2006).

Kerić, E., Radanović, I., Lukša Ž., Garašić, D., Sertić Perić, M. 2017. Utjecaj aktivne nastave na učenje ekoloških sadržaja u osnovnoj školi. Educ. biol. 3, 1, 1-14. 
Uspješnost učenja kontrolnog odjeljenja prisutna je i raste, ali daleko manjim intenzitetom i sporije nego kod odjeljenja uključenih u aktivnu nastavu. Podatci o postignutim rezultatima učenika mogu biti dobra osnova za analizu ostvarenog uspjeha pojedinog zadatka u nastavi, ali i predviđanje uspjeha učenika. Logaritamski oblik regresije bolje objašnjava postignuti uspjeh učenika, ali linearni model još uvijek pokazuje zadovoljavajuću pouzdanost te umanjuje značaj rijetkih pojedinačnih rezultata uspješnosti. Zbog toga je linearni model bolje koristiti za prikaz ukupne slike uspješnosti u provjerama znanja. Takve rezultate podržavaju i istraživanja drugih autora te su Freyberger i sur. (2004) logističku regresiju koristili za predviđanje točnog odgovora na pitanje pri e-učenju i određivanje modela prijenosa kako bi predvidjeli uspjeh učenika, dok su Myller i sur. (2002) linearnu regresiju koristili za predviđanje rezultata ispitivanja u tečajevima obrazovanja na daljinu. $\mathrm{Na}$ osnovu analize postignutih rezultata učenika u pisanim provjerama utvrđeno je da manji odsječak na osi y uz primjenu linearne regresije pokazuje slabiju uspješnost pri rješavanju zadataka, a položenost regresijske linije ukazuje na veću ujednačenost uspjeha kod ispitivanih učenika, što je dobra povratna informacija o karakteristikama provjere i učenika koji su je rješavali.

Učenici kontrolnog odjeljenja su, kako je vrijeme odmicalo, pokazivali sve lošije znanje, bez velikog napretka iako su na nastavi tijekom sata bili usmjereni samostalnom radu i kreativnosti. $U$ anketnom su upitniku bolje procijenili tehnike rada koje uključuju veću aktivnost i manju vezu s tradicionalnim oblikom nastave. Sukladno tome Labak i sur. (2014) utvrdili su da učenici smatraju kako im je učenje i pamćenje olakšano kada se aktivne metode primjenjuju tijekom dužeg vremena i u blok satima. Uspješnost učenika kontrolne skupine opada velikim intenzitetom, jednako kako se smanjuje i njihova motivacija. Mnogi autori ukazuju na povezanost motivacije i uspješnosti (Matijević, 2008; Bilić 2001), a prema Furlanu (1984) na razvoj motivacije značajno utječe uspjeh postignut vlastitim učenjem i radom. Tako je razvoj unutarnje motivacije moguće ostvariti preko vanjskih čimbenika kao što je dobro strukturirani zadatak u prirodi (Kirschner i sur, 2006), u kom učenici nalaze zanimljivost i životnu primjenjivost i koji potiče situacijski interes kod učenika. Nakon sudjelovanja i truda uloženog u izradu projekata i nastavu na satu učenici su pokazali bolju uspješnost učenja, te su i sami izrazili želju da i u budućnosti nešto rade sami, što je u skladu sa zaključkom Michaela (2006) koji ističe da postoji mnogo opcija iz kojih možemo birati te da svi trebamo početi reformirati našu poduku, primjenjujući one posebne pristupe za poticanje aktivnog učenja koje odgovaraju potrebama naših učenika, našim pojedinačnim nastavnim satovima i vlastitim stilovima poučavanja. Većina učenika prepoznaje najbolje učinke učenja uz mogućnost samostalnog rada, ali uz kontinuiranu povratnu informaciju i dobru potporu, usmjeravanje kao i sistematizaciju nastavnika, čime se potvrđuje neophodna visoko razvijena facilitatorska uloga nastavnika (Kirschner i sur, 2006) kao neizostavna kompetencija u primjeni aktivnog učenja. Zbog toga nastavnicima treba tijekom edukacije omogućiti primjenu više modela poučavanja i u učionici i na terenu, u skladu s individualnim potrebama za podrškom pri poučavanju ili pomoći i vođenju pri učenju za učenike. Za razliku od toga interes učenika kontrolnog odjeljenja za temu završava sa završetkom nastavnog sata. Od njih se nije zahtijevao niti očekivao nikakav dodatni rad, što je u konačnici vjerojatno rezultiralo i smanjenjem uspješnosti učenja.

\section{ZAKLJUČAK}

Učenici šestih razreda osnovne škole doživljavaju nastavu Prirode najzabavnijom kad se odvija izvan učionice, u prirodi, te svaki oblik rada koji im omogućuje slobodu istraživanja i rada izvan učionice doživljavaju pozitivno. Učenici uključeni u aktivnu nastavu postaju slobodniji u iskazivanju ideja i misli,

Kerić, E., Radanović, I., Lukša Ž., Garašić, D., Sertić Perić, M. 2017. Utjecaj aktivne nastave na učenje ekoloških sadržaja u osnovnoj školi. Educ. biol. 3, 1, 1-14. 
ne doživljavaju učitelja kao strogu figuru već kao mentora, osobu kojoj se mogu obratiti za pomoć i osobu koja njih doživljava kao osobe. Uz mentorski rad nastavnika učenicima je neophodna sistematizacija, usmjeravanje uz kontinuiranu povratnu informaciju.

Razvijanjem svijesti da su jednakovrijedni i sposobni sami riješiti zadane probleme raste motivacija za rad i uspješnost u učenju. Uvođenje projekata u nastavu zahtijeva od učitelja iscrpnu pripremu, jer mora pripremiti sve moguće scenarije događaja kako bi učenici u njemu imali stalni oslonac i pomoć $i$ kako bi se u svakom trenutku osjećali sigurno. Poželjno je uvesti aktivnu nastavu u svim odjeljenjima, jer rezultati pokazuju da učenici ne reagiraju dobro ukoliko se osjećaju zakinuti ili isključeni. lako većina učenika dobro prihvaća rad na projektnim zadacima, dio učenika ne prihvaća grupni rad i teže surađuje u grupi. Stoga nastavnik treba omogućiti kombinaciju različitih socioloških oblika rada kako bi svi učenici mogli razviti svoje sposobnosti. Važno je primijetiti i da većina učenika preferira kombinaciju nastavnikova više ili manje strukturiranog vođenja i samostalnog rada što ukazuje na važnost sistematizacije kod aktivnih oblika rada u nastavi.

Za analizu i predviđanje uspjeha učenika pri rješavanju zadataka pisane provjere može se koristiti linearni model koji pokazuje zadovoljavajuću pouzdanost te umanjuje značaj rijetkih pojedinačnih rezultata uspješnosti. Pri tome manji odsječak na osi y pokazuje slabiju uspješnost pri rješavanju zadataka, a položenost regresijske linije ukazuje na veću ujednačenost uspjeha kod ispitivanih učenika, što je dobra povratna informacija o karakteristikama provjere i učenika koji su je rješavali.

\section{METODIČKI ZNAČAJ}

Dobar odabir tema i prilagođenost projekata psihofizičkim sposobnostima učenika omogućit će da grupni rad $i$ istraživanje u prirodi postigne željeni učinak, učenici će željeti znati više, više će se truditi da budu uspješniji u radu što je pokazalo i ovo istraživanje. Učenici su bili više motivirani za nastavu Prirode, uspješniji u učenju i zaključivanju i uživali su u nastavi u prirodi. Stoga upravo primjena aktivne nastave, prvenstveno uz terenski rad, može biti dobro rješenje za održavanje motivacije i zainteresiranosti učenika za nastavu uz podržavanje situacijskog interesa aktivnostima učenja. To će značiti da i mi kontinuirano tijekom nastave učimo kako poučavati i učiti zajedno s našim učenicima prilagođavajući nastavu njihovoj i svojom osobnosti, interesima i mogućnostima izvedbe. Važnost osobnosti nastavnika pri organizaciji terenske nastave uočavaju i Scott i suradnici (2015) koji su zaključili da je predodređenost pojedinca za terenskim aktivnostima u biologiji ključna za otvorenost $u$ pronalasku vrijednost osposobljavanja vezanog za poučavanje na terenu, čime je potvrđena potreba uvažavanja osobnosti kao važnom čimbeniku kako pri bazičnom osposobljavanju tako i pri usavršavanju nastavnika.

\section{ZAHVALA}

Istraživanje je provedeno za potrebe projekta Kompetencije učenika u nastavi prirode i biologije br. 119-00913611223, uz odobrenje i potporu MZOŠ-a Republike Hrvatske. Zahvaljujemo se Vlasti Bendelja prof. biologije i njenim učenicima na sudjelovanju i suradnji pri istraživanju.

\section{LITERATURA}

Abrahams I. 2009. Does Practical Work Really Motivate? A study of the affective value of practical work in secondary school science, International Journal of Science Education, 31, 17, 2335-2353, DOI: 10.1080/09500690802342836.

Baranović, B. 2006. Nacionalni kurikulum za obvezno obrazovanje u hrvatskoj; različite perspektive. Zagreb, Institut za društvena istraživanja

Bilić ,V. 2001. Uzroci, posljedice i prevladavanje školskog neuspjeha. Zagreb, Hrvatski pedagoško-književni zbor

Kerić, E., Radanović, I., Lukša Ž., Garašić, D., Sertić Perić, M. 2017. Utjecaj aktivne nastave na učenje ekoloških sadržaja u osnovnoj školi. Educ. biol. 3, 1, 1-14. 
Bogner, F.X. 1998. The influence of short-term outdoor education on long- term variables of environmental perspective. Journal of Environmental Education, 29, 4, 17-29.

Borić, E., Peko, A., M. Vujnović 2002. Od riječi do djela u nastavi prirode i biologije. Život i škola, 48, 7, $117-124$.

Borresen, C. R. 1990. Success in introductory statistics with small groups. College Teaching, 38,1, 26-28.

Dillon, J. , Rickinson, M., Teamey K., Morris, M., Choi, M.J., Sanders, D., Benefield P. 2006. The value of outdoor learning: evidence from research in the UK and elsewhere. School Science Review, 87, 320, 107-111.

Dryden, G., J. Vos 2001. Revolucija u učenju - kako promijeniti način na koji svijet uči. Zagreb, Educa.

Freyberger, J., Heffernan, N.T., Ruiz, C. (2004). Using Association Rules to Guide a Search for Best Fitting Transfer Models of Student Learning. Workshop Analyzing Student-Tutor Interaction Logs to Improve Educational Outcomes, Alagoas, Brazil, 1-10.

Furlan, I. 1984. Primijenjena psihologija učenja. Zagreb, Školska knjiga.

Garašić, D. 2012. Primjerenost biološkog obrazovanja tijekom osnovnog i gimnazijskog školovanja. Sveučilište u Zagrebu, Prirodoslovno-matematički fakultet, doktorska disertacija 05.07. 2012., 348 str.

Glasser, W. 1994. Kvalitetna škola. Zagreb, Educa.

Greaves, E., Staimsstreet, M., Boyes E., T. Williames 1993. Childrens ideas about rainforest. Journal of Biological Education, 27,3, 189-94.

Hidi, S., Harackiewicz, J. M. 2000. Motivating the academically unmotivated: A critical issue for the 21 st century. Review of Educational Research, 70, 2, 151-179.

Hodson, D. 1996. Practical work in school science: exploring some directions for change. International Journal of Science Education, 18, 7, 755-760.

Jensen, E. 2003. Super-nastava: nastavne strategije za kvalitetnu školu i uspješno učenje. Zagreb, Educa.

Jokić, B. 2008. Science and Religion in Croatian Elementary Education. Pupils' Attitudes and Perspectives. University of Cambridge, Faculty of Education, doctoral dissertation.

Kirschner, P. A., Sweller, J., Clark, R. E. 2006. Why minimal guidance during instruction does not work: an analysis of the failure of constructivist, discovery, problem-based, experiential, and inquiry-based teaching. Educational Psychologist, 41, 2, 75-86.

Labak, .I, Heffer, M., Radanović, I. 2014. Stavovi učenika o nastavi prirode i biologije organiziranoj u dvosatu. Educatio Biologiae, 1, 26-39.

Labov, J. B., Reid, A. H. Yamamoto, K. R. 2010. Integrated Biology and Undergraduate Science Education: A New Biology Education for the Twenty-First Century?. CBE-Life Sciences Education, 9, 10-16.

Lorenzo, M., Crouch, C. H. , Mazur, E. 2006. Reducing the gender gap in the physics classroom. American Journal of Physics, 74, 118-122, DOI: 10.1119/1.2162549.

Lukša, Ž. 2007. Akademska postignuća učenika u grupnom radu u nastavi biologije. Napredak, 148, 4, 549-564.

Martin, W. W., Falk, J. H., J.D. Balling 1981. Environmental effects on learning: the outdoor field trip. Science Education, 65, 3, 301-309.

Matijević, M. 2008. Projektno učenje i nastava. Zagreb, Znamen.

Michael J. 2006. Where's the evidence that active learning works? Adv Physiol Educ, 30, 159-167, D0l:10.1152/advan.00053.2006. MZOŠ 2005. Vodič kroz Hrvatski nacionalni obrazovni standard za osnovnu školu - HNOS. Zagreb, MZOŠ.

Myller, N., Suhonen, J., Sutinen, E. (2002). Using Dana Mining for Improving Web-Based Course Design. International Conference on Computers in Education, Washington, 959- 964.

Oyerinde, O. D., Chia, P. A. 2017. Predicting Students' Academic Performances - A Learning Analytics Approach using Multiple Linear Regression. International Journal of Computer Applications (0975 - 8887), 157, 4, 37 - 44.

Preston, L., Griffiths, A. 2004. Pedagogy of connections: Findings of a collaborative action research project in outdoor and environmental education. Australian Journal of Outdoor Education, 8, 2, 36-45.

Radanović I., Lukša Ž., Pongrac Štimac Z., Garašić D., Bastić M., Kapov S., Kostanić LJ., Sertić Perić M., Toljan M. 2017. Sadržajna i metodološka analiza ispita državne mature iz Biologije u školskoj godini 2015./2016. NCVVO Zagreb $212 \mathrm{str}$.

Rickinson, M., Dillon, J., Teamey, K., Morris, M., Choi, M. Y., Sanders, D., Benefield, P. 2004. A review of research on outdoor learning. Preston Montford, Shropshire: Field Studies Council.

Ros, R., Gott, R. 2003. Assessment of biology investigations. Journal of Biological Education, 37, 3, 114-121.

Siendentop, W. 1971. Metodik und Didaktik Biologienunterricht. Heidelberg, Verlag Quelle und Meyer

Slavin, R.E. 1995. Reasearch on cooperative learning and achievement: What we know, what we need to know. Contemporary Educational Psychology, 21, 43-69.

Scott, G. W., Boyd, M., Scott L., Colquhoun D. 2015. Barriers To Biological Fieldwork: What Really Prevents Teaching Out of Doors?. Journal of Biological Education, 49, 2, 165-178, DOI: 10.1080/00219266.2014.914556. 